\title{
Sex Differences in Self- and Teachers' Reports of Self-Esteem in Preadolescents ${ }^{1}$
}

\author{
Roger C. Loeb ${ }^{2}$ and Leslie Horst ${ }^{3}$ \\ Lehigh University
}

The short form of the Coopersmith Self-Esteem Inventory was administered to 952 fourth-and fifth-grade children (482 males, 470 females) from 41 classes. The children's teachers completed Coopersmith's Behavior Rating Form, a measure of self-esteem-related behavior. In the self-ratings, girls were significantly lower than boys; in the teachers' ratings, girls were significantly higher. In 32 of the 41 classes, boys ranked higher in their self-ratings than in the teacher ratings; the reverse was true for girls - a highly significant difference. This pattern of findings did not occur in the 8 classes which had male teachers. Issues concerning the measurement and conceptualization of self-esteem are discussed.

Since the mid-1960s, much research has been focused on sex differences in selfesteem. The present study was undertaken to help clarify the nature of sex differences in self-rated and teacher-rated self-esteem, and the relationship between the two measures. In the context of this research, a number of important questions concerning the measurement and conceptualization of self-esteem have arisen.

Recent studies on sex differences in self-esteem have used a wide variety of instruments and have produced an equally varied set of results. Perhaps the most frequent finding is an absence of statistically significant sex differences in selfreported self-esteem (Carlson, 1965; Carpenter \& Busse, 1969; Damico, 1975;

\footnotetext{
${ }^{1}$ This research was supported by Lehigh University, using Institutional Grant funds from the National Science Foundation. The authors wish to express their appreciation to Patricia Horton for her assistance in the collection of the data.

${ }^{2}$ All correspondence should be sent to Roger C. Loeb, Department of Behavioral Sciences, The University of Michigan at Dearborn, 4901 Evergreen Road, Dearborn, Michigan 48128.

${ }^{3}$ Now at Women's Studies Program, San Diego State University, San Diego, California 92182.
} 
Friedman, Rogers, \& Gettys, 1975; Harris \& Braun, 1971; Kokenes, 1974a; Lekarczyk \& Hill, 1969; Long, Henderson, \& Ziller, 1967; Nisbett \& Gordon, 1967; Powelkiewick \& McIntyre, 1975; Reschly \& Mittman, 1973; Simon \& Simon, 1975; Smith, Tedeschi, Braun, \& Lindskold, 1973; Vance \& Richmon, 1975). In many of these studies the means are not given, so it is not possible to discern trends.

A few studies have found females significantly higher than males (Baum et al., 1970; Bledsoe, 1967; Campbell, 1966), though this result appears to be rare. In some cases, either in the whole sample or in a subsample, males score higher than females (Whittaker, 1973; Durley, 1974; Good \& Good, 1975; Fein, O'Neill, Frank, \& Velit, 1975; Kimball, 1973; Herbert, Gelfand, \& Hartmann, 1969; Carpenter \& Busse, 1969). In these studies, males tended to exceed females in the older age groups (late elementary, junior high, and college age). Fein et al. (1975) tested 307 urban children ranging from 7 to 13 years old. They found a sex by grade interaction in which the girls' scores appeared to stay the same, but the boys' scores increased with age. This result was taken as support for Bardwick's notion (1971) that girls have a difficult time in early adolescence and show a decrease in self-esteem, relative to boys, at that age.

Other studies do not report or discuss sex differences in self-esteem measures, even though they have the data (Bagley \& Evan-Wong, 1975; Kokenes, 1974b; Lewis \& Adank, 1975; Spotz \& Johnston, 1973). These studies were usually focused on other aspects of self-esteem.

There are data from other research areas relevant to the issue of sex differences in self-esteem. Several experiments by V. C. Crandall (1969) found that boys expect to perform better than girls do and that boys tend to overestimate their expected performance relative to their actual performance while girls underestimate. Lekarczyk and Hill (1969) found that boys were higher than girls on "lie" and "defensiveness" scales. (They eliminated subjects in the highest $5 \%$ on these two measures, which may be why they found no sex differences in self-esteem). Similarly, Maccoby and Jacklin (1974) point out the possible effect of defensiveness on boys' self-esteem scores. From these studies we are led to Hypothesis I: Boys will score higher than girls on self-ratings of self-esteem.

Many of the studies cited earlier had relatively small samples $(n<100)$, and all relied on a single self-report of self-esteem. Coopersmith's study (1967) is distinguished from many others both by the large size of the sample and by the use of two separate indices of self-esteem. He found no significant sex differences in the self-ratings (perceptions) of 10- to 12-year-old children. However, teachers' ratings of these same children's self-esteem-related behaviors resulted in significantly higher scores for the girls. This discrepancy between self- and teachers' reports was not discussed by Coopersmith and has received little attention since.

One study which used teacher ratings (Amatora, 1955) reported that teachers rated both boys and girls higher in desirable personality characteristics than the children rated themselves. However, self-esteem was not the focus of 
Amatora's study, and differences between girls and boys in teachers' ratings were not reported.

Several recent studies have used Coopersmith's self- and teacher-rating instruments together, although almost none of these studies has discussed sex differences (Altman \& Firesz, 1973; Altman \& Scollon, 1973; Ammerman \& Fryrear, 1975; Cress \& O'Donnell, 1975). One additional study (Damico, 1975) included the Coopersmith self-report measure and the "Florida key" (a measure of inferred learner self-concept) which is completed by the teacher. There were no significant sex differences in this study, but the sample size (30) was quite small.

In just a few studies, adults other than teachers have rated children's selfconcept. Rothbart and Maccoby (1966) played a tape of a 4-year-old's voice to parents of children of nursery school age. Subjects were asked to imagine that they were parents of the taped child in giving their responses. When the assigned sex of the child was the opposite of the subject's (e.g., male subject with female child), the child was responded to with more permissiveness and positive attention than when the subject and the hypothetical child were the same sex. Gurwitz and Dodge (1975) found the same pattern of favorable opposite-sex ratings when college students watched a videotape of a 3-year-old child. A weakness of both these studies is that they used only one tape each; factors unique to each tape might have affected the results. Contradictory findings have been reported. For instance, a study with a large sample (Shrader \& Leventhal, 1968) found no sex differences in parents' ratings of their children's "self-feeling." Furthermore, there is evidence that female teachers are more likely to value "feminine" behavior in preschool children (Fagot \& Patterson, 1969), which suggests that the pattern of cross-sex preference noted by Gurwitz and Dodge and Rothbart and Maccoby is not a general one.

Evidence concerning older children is more indirect, although some social commentators (e.g., Sexton, 1969) suggest that in elementary school, teachers tend to favor "feminine" behavior, and studies by Kagan (1964) and Kellogg (1969) have found that children tend to perceive school objects as "feminine." Since "feminine" behavior is associated with the school setting and is viewed as desirable, teachers may perceive girls more favorably than boys. Thus, we postulate Hypothesis II: Girls will score higher than boys in teachers' ratings of self-esteem-related behaviors. The lines of reasoning used to formulate Hypotheses I and II also lead to Hypothesis III: Boys will score higher on self-ratings than on teacher ratings, while the reverse will be true for girls.

Since several studies (Gurwitz \& Dodge, 1975; Meyer \& Sobieszek, 1972; Rothbart \& Maccoby, 1966) suggest that sex differences in the observer may affect the way boys and girls are perceived, the sex of the teacher should be considered. Unfortunately, this factor was not discussed by Coopersmith.

Differences between self- and teacher ratings of self-esteem such as Coopersmith found are meaningful if you believe with Coopersmith (1959) that such ratings reflect different aspects or perceptions of self-esteem and may be re- 
lated to differing student characteristics. This belief is supported by the Cress and O'Donnell (1975) study which reported that teacher ratings for a sample of Oglala Sioux adolescents correlated with grade point average, while self-ratings did not. The alternative is to claim that the differences in the results obtained indicate that either or both measures are invalid. However, Coopersmith (1967) found meaningfully different patterns of characteristics for subjects who were high on one measure and low on the other. This differential pattern of findings, consistent with Coopersmith's predictions, seems to provide support for the validity of both measures. In addition, many of the studies cited earlier provide support for the validity of Coopersmith's self-rating measure. Therefore, the view taken in this study is that self- and teachers' reports are both reasonable measures of different aspects of self-esteem. Given the usefulness of this twofactor approach, it is necessary to answer several questions: (1) Will Coopersmith's results be replicated in a present-day sample? (2) Will sex differences follow the patterns predicted in the three hypotheses above? (3) Will the results differ for classes with male and female teachers?

\section{METHOD}

\section{Subjects}

The subjects were 952 (482 male, 470 female) fourth- and fifth-graders from predominantly White lower-middle- to upper-middle-class schools in A1lentown, Pennsylvania (population, approximately 110,000). The students came from 41 classes in eight schools; of these, 33 classes had female teachers and 8 had male teachers.

\section{Procedure}

All students present on the testing day were administered a short form of Coopersmith's Self-Esteem Inventory, which has been reported to correlate .95 with the long form (R. Crandall, 1973). ${ }^{4}$ This scale consists of 25 "like meunlike me" items (e.g., "I'm a lot of fun to be with") resulting in a potential score of 0 to 25. The teachers were asked to fill out Coopersmith's Behavior Rating Form (1967). The 10 items (e.g., "Does this child show confidence and

\footnotetext{
${ }^{4} \mathrm{R}$. Crandall reported that this scale correlated .54 and .60 with Rosenberg's self-esteem measure in two different studies. The short scale has almost the same proportions of items as the long form in the four content areas designated by Coopersmith (general self, home and parents, school-academics, social self and peers). The same four content areas were found in Kokenes' massive factor analy tic study (1974a, 1974b).
} 
assurance in his/her actions towards his/her teachers and classmates?") were scored 0 to 4 (indicating the degree to which the teacher thought the student performed certain behaviors) and resulted in a potential score of 0 to 40 . Only the 952 students for whom both pieces of information were received are included in the sample.

As in Coopersmith's work (1967), teachers varied greatly in their use of the Behavior Rating Form's scale of measurement. The ranges of scores assigned by teachers varied from 10 to 33 points. To handle these scale differences, sex differences were assessed within each individual teacher's classroom as well as in the total sample.

In order to make comparisons between teachers' behavioral ratings and students' self-esteem reports, it was necessary to assign each student's score a rank relative to his or her classroom group on both the Behavior Rating Form and the Self-Esteem Inventory. A comparison of the raw scores would have been inappropriate, as the two scores were derived from quite different measures. Mean ranks on the two measuring instruments were computed and the ranks of the teachers' ratings and the students' scores compared for both boys and girls.

The following information was gathered for each class: (a) Did males or females rate themselves higher on the Self-Esteem Inventory (questions 1 and 2 above)? (b) Were males or females rated higher by the teachers on the Behavior Rating Form (questions 1 and 2 above)? (c) Did males rank higher on the SelfEsteem Inventory than on the Behavior Rating Form, and did females rank higher on the Behavior Rating Form than on the Self-Esteem Inventory (question 2 above)? All of these analyses were repeated for the female and male teachers separately (question 3 above).

\section{RESULTS}

The first set of data to be reported is the students' self-reports. Their scores on the Self-Esteem Inventory ranged from 1 to 25, with means of 14.02 for girls $(s d=4.76)$ and 15.18 for boys ( $s d=4.84)$. Boys had a significantly higher score than girls, $t(950)=3.74, p<.001 .^{5}$ Using classes as the unit of analysis, the same pattern was found. In 28 classes, the average score for boys on the Self-Esteem Inventory was higher than the average score for girls. In 13 classes, the reverse was true. The sign test on these data was statistically significant $(z=2.19 p<.03){ }^{6}$ Males are clearly rating themselves higher in selfesteem, thus confirming Hypothesis I.

The second set of data is the teachers' reports of their students' esteemrelated behaviors. The teachers' ratings on the Behavior Rating Form ranged

\footnotetext{
${ }^{5}$ All $p$ levels are for two-tailed tests.

${ }^{6}$ All $z$ approximations to the sign test included the correction for continuity (Siegel, 1956).
} 
from 4 to 40 , with a mean for girls of $25.62(s d=6.63)$ and for boys of 24.11 $(s d=6.71)$. This is a significantly higher score for girls, $t(950)=3.53, p<.001$. Here, because of differences in the teachers' use of the scale, an analysis within classes is particularly needed. Twenty-seven teachers rated girls on the average higher than boys, while 14 teachers rated boys higher. A sign test for these data was nearly significant $(z=1.88, p<.06)$. Apparently, the teachers perceive girls as possessing somewhat more positive esteem-related behaviors than boys, and Hypothesis II is supported.

The third set of data is the comparison between the two measures for boys and girls. In 32 classes, the boys had higher rank on the Self-Esteem Inventory than on the Behavior Rating Form. In 9 classes, the pattern for boys was the reverse. Girls necessarily were the opposite. The sign test on these data was highly significant $(z=3.44, p<.001)$. The predicted sex reversal seems to exist. Boys rate themselves higher than their teachers rate them. Girls are rated higher by their teachers than they rate themselves. Hypothesis III is strongly supported.

When these analyses were done separately by sex of teacher, the results for female teachers were in the same direction as those for the whole group. This is not surprising, since 33 of the 41 teachers were female. In the 8 classes taught by males, the pattern was the reverse of that found with female teachers. While none of the results with male teachers is significant and the sample is small, the contrast in results merits consideration in future research.

\section{DISCUSSION}

Coopersmith found that teachers rated girls significantly higher than boys on behaviors related to self-esteem, but he did not find a significant difference between boys' and girls' self-ratings of self-esteem. The present research resulted in a similar findings for teachers' ratings; but, unlike Coopersmith, we found significantly higher self-rated self-esteem scores for the boys.

The findings concerning the differential predictions for self-ratings versus ratings by teachers for males and females are particularly striking. Boys rate themselves higher than girls in self-esteem. However, teachers - at least female teachers (who predominate during the elementary years) - rate boys lower than girls in self-esteem-related behaviors. Many of the explanations suggested earlier could be given for this difference; for example, teachers value quiet, polite, "feminine" behavior; boys may give overly positive responses, while girls may give unduly modest responses. The boys may perceive the teachers' relatively low evaluations of them and respond by basing their self-esteem primarily on other indications of success rather than by consistently lowering their selfesteem (there is much other societal support for the former alternative). The 
girls may realize that the behaviors and characteristics valued by their teachers are not those most valued or rewarded by society at large (Broverman, Broverman, Clarkson, Rosenkrantz, \& Vogel, 1970; McKee \& Sherriffs, 1957).

If boys are not receiving any particular support for their self-esteem from teachers, then they presumably have alternative sources of self-esteem. One of these may be academic achievement. A positive correlation between self-concept and achievement has often been reported for boys, with a less strong or no correlation for girls (Purkey, 1970; Campbell, 1966; for sixth graders in Piers and Harris, 1969; Fein et al., 1975; Fink, 1962). These findings suggest that success in academics may foster a positive self-concept in boys. Alternatively, a good self-concept may aid boys' academic achievement. Academic success may not be a particularly significant aid to girls' positive self-concept, even though girls generally receive higher grades from their teachers in elementary school (Bardwick, 1971; Parsons, Ruble, Hodges, \& Small, 1976). An alternative explanation is that a lower self-concept relative to boys may not interfere with girls' academic achievement. The results seem to suggest that in terms of self-esteem, if there is an important academic component, it is some form of achievement other than pleasing the teacher.

It was noted earlier that Coopersmith did not mention the sex of the teachers. In the present study, the finding that teachers give girls higher ratings while boys give themselves higher ratings was only clear in the classrooms with female teachers. This result may simply reflect the smallness of the sample of male teachers, but it also suggests that teachers' perceptions of their students may be influenced by the sex of the teacher as well as by the sex of the child.

Finally, our results seem to raise questions about the use of these measures in research. Can both instruments be accurate and meaningful measures of "selfesteem" if they produce different results? R. Crandall (1973) reports several studies demonstrating both reliability (split-half and test-retest) and convergent validity for the Self-Esteen Inventory. Coopersmith (1967) has reported high reliability (test-retest and inter-rater) for the Behavior Rating Form. The validity of the two measures was supported in Coopersmith's monograph (1967), as described earlier. His findings demonstrate the utility of considering each measure as contributing to a meaningful understanding of self-esteem. Our findings suggest that boys and girls may truly differ on these two aspects. Our results also strongly suggest that the sexes differ in their relative ranking on the measures, with girls being higher in teacher ratings than in self-ratings, and the reverse being true for boys. However, at this point we cannot rule out the possibility that our findings are method dependent. A strategy for replicating our findings might use two nonoverlapping scales for each of the two measures - self-ratings and teacher ratings - to test our findings by the method of converging operations. This approach would also allow inferences concerning sex differences in the different situational contexts for the expression of self-esteem. 


\section{REFERENCES}

Altman, H. A., \& Firesz, K. M. A role playing approach to influencing behavior change and self-esteem. Elementary School Guidance and Counseling, 1973, 7, 276-281.

Altman, H. A., \& Scollon, J. The influence of process variables on self-esteem. Psychology, $1973,10,37-43$.

Amatora, M. Comparisons in personality self-evaluation. Journal of Social Psychology, $1955,42,315-321$.

Ammerman, M. S., \& Fryrear, J. L. Photographic enhancement of children's self-esteem. Psychology in the Schools, 1975, 12, 319-325.

Bagley, C., \& Evan-Wong, L. Neuroticism and extraversion in response to Coopersmith's Self-esteem Inventory. Psychological Reports, 1975, 36, 253-254.

Bardwick, J. M. Psychology of Women. New York: Harper \& Row, 1971.

Baum et al. In W. W. Purkey, Self concept and school achievement. Englewood Cliffs, N.J.: Prentice-Hall, 1970.

Bledsoe, J. C. Self-concepts of children and their intelligence, achievement, interests, and anxiety. Childhood Education, 1967, 43, 436-438.

Broverman, I. K., Broverman, D. M., Clarkson, F. E., Rosenkrantz, P., \& Vogel, S. R. Sex role stereotypes and clinical judgments of mental health. Joumal of Consulting and Clinical Psychology, 1970, 34, 1-7.

Campbell, P. B. Self-concept and academic achievement in middle grade public school children (Doctoral dissertation, Wayne State University, 1965). Dissertation $A b$ stracts International, 1966, 27, 1535A-1536A. (University Microfilms No. 66-10, 103).

Carlson, R. Stability and change in the adolescent's self-esteem. Child Psychology, 1965, $36,659-666$.

Carpenter, T. R., \& Busse, T. V. Development of self-concept in Negro and White welfare children. Child Development, 1969, 40, 935-939.

Coopersmith, S. A method for determining two types of self-esteem. Journal of Abnormal and Social Psychology, 1959, 59, 87-94.

Coopersmith, S. The antecedents of self-esteem. San Francisco: W. H. Freeman, 1967.

Crandall, R. The measurement of self-esteem and related constructs. In J. P. Robinson \& P. R. Shaver (Eds.), Measures of social psychological attitudes (rev. ed.). Ann Arbor, Mich.: Institute for Social Research, 1973.

Crandall, V. C. Sex differences in expectancy of intellectual and academic reinforcement. In C. P. Smith (Ed.), Achievement related motives in children. New York: Russell Sage, 1969.

Cress, J. N., \& O'Donnell, J. P. The self-esteem inventory and the Oglala Sioux: A validation study. Journal of Social Psychology, 1975, 97, 135-136.

Damico, S. B. Sexual differences in the responses of elementary pupils to their classroom. Psychology in the Schools, 1975, 12, 462-467.

Durley, G. L. A variance analysis of the self-esteem among Black elementary school children: Sex and grade level the determining variables. (Doctoral dissertation, University of Massachusetts, 1973). Dissertation Abstracts International, 1974, 34, 6514A-6515A. (University Microfilms No. 74-8592.)

Fagot, B. I., \& Patterson, G. R. An in vivo analysis of reinforcing contingencies for sex-role behaviors in the preschool child. Developmental Psychology, 1969, 1, 563-568.

Fein, D., O'Neill, S., Frank, C., \& Velit, K. M. Sex differences in preadolescent self-esteem. Journal of Psychology, 1975, 90, 179-183.

Fink, M. B. Self-concept as it relates to academic achievement. California Journal of Educational Research, 1962, 13, 57-62.

Friedman, S., Rogers, P. P., \& Gettys, J. Project re-ed: Increase in self-esteem as measured by the Coopersmith Inventory. Perceptual and Motor Skills, 1975, 40, 165-166.

Good, L. R., \& Good, K. C. A measure of self-esteem. Psychology, 1975, 12, 32-34.

Gurwitz, S. B., \& Dodge, K. A. Adults' evaluations of a child as a function of sex of adult and sex of child. Journal of Personality and Social Psychology, 1975, 32, 822-828. 
Harris, S., \& Braun, J. R. Self-esteem and racial preference in black children. Proceedings of the 79th Annual Convention of the American Psychological Association, 1971, 8, 259-260.

Herbert, E. W., Gelfand, D. M., \& Hartmann, D. P. Imitation and self-esteem as determinants of self-critical behavior. Child Development, 1969, 40, 421-430.

Kagan, J. The child's sex-role classification of school objects. Child Development, 1964 , $35,1051-1056$.

Kellogg, R. L. A direct approach to sex-role identification of school-related objects. Psychological Reports, $1969,24,839-841$.

Kimball, O. M. Development of norms for the Coopersmith Self-Esteem Inventory: Grades four through eight. (Doctoral dissertation, Northern Illinois University, 1973). Dissertation Abstracts International, 1973, 34, 1131A-1132A. (University Microfilms No. 73-20, 551).

Kokenes, B. M. A factor analy tic study of the Coopersmith Self-Esteem Inventory. (Doctoral dissertation, Northern Illinois University, 1973). Dissertation Abstracts International, 1974, 34, 4877A. (University Microfilms No. 74-2800). (a)

Kokenes, B. Grade level differences in factors of self-esteem. Developmental Psychology, $1974,10,954-958$. (b)

Lekarczyk, D. T., \& Hill, K. T. Self-esteem, test anxiety, stress, and verbal learning. Developmental Psychology, 1969, 1, 147-154.

Lewis, J., \& Adank, R. Intercorrelations among measures of intelligence, achievement, selfesteem, and anxiety in two groups of elementary school pupils exposed to two different models of instruction. Educational and Psychological Measurement, 1975, 35, 499-501.

Long, B. H., Henderson, E. H., \& Ziller, R. C. Developmental changes in the self-concept during middle childhood. Merrill-Palmer Quarterly, 1967, 13, 201-215.

Maccoby, E. E., \& Jacklin, C. N. The psychology of sex differences. Stanford: Stanford University Press, 1974.

McKee, J. P., \& Sherriffs, A. C. The differential evaluation of males and females. Journal of Personality, 1957, 25, 356-371.

Meyer, J. W., \& Sobieszek, B. J. The effect of a child's sex on adult interpretations of its behavior. Developmental Psychology, 1972, 6, 42-48.

Nisbett, R. E, \& Gordon, A. Self-esteem and susceptibility to social influence. Journal of Personality and Social Psychology, 1967, 5, 268-276.

Parsons, J., Ruble, D. N., Hodges, K., \& Small, A. W. Cognitive-developmental factors in emerging sex differences in achievement-related expectancies. Journal of Social Issues, 1976, 32, 47-61.

Piers, E., \& Harris, D. Manual for the Piers-Harris Children's Self Concept Scale. Nashville, Tenn.: Counselor Recordings and Tests, 1969.

Powelkiewick, W. M., \& McIntyre, W. G. Field dependence-independence and self-esteem in preadolescent children. Perceptual and Motor Skills, 1975, 41, 41.42.

Purkey, W. W. Self concept and school achievement. Englewood Cliffs, N.J.: Prentice-Hall, 1970.

Reschly, D. J., \& Mittman, A. The relationship of self-esteem status and task ambiguity to the self-reinforcement behavior of children. Developmental Psychology, 1973, 9, 16-19.

Rothbart, M. K., \& Maccoby, E. E. Parents' differential reactions to sons and daughters. Journal of Personality and Social Psychology, 1966, 4, 237-243.

Sexton, P. C. The feminized male: Classrooms, white collars, and the decline of manliness. New York: Random House, 1969.

Shrader, W. K., \& Leventhal, T. Birth order of children and parental report of problems. Child Development, 1968, 39, 1165-1175.

Siegel, S. Non-parametric statistics. New York: McGraw-Hill, 1956.

Simon, W. E., \& Simon, M. G. Self-esteem, intelligence, and standardized academic achievement. Psychology in the Schools, 1975, 12, 97-100. 
Smith, R., Tedeschi, J. T., Braun, R. C., \& Lindskold, S. Correlations between trust, selfesteem, sociometric choice, and internal-external control. Psychological Reports, $1973,32,739-743$.

Spotz, K. C., \& Johnston, J. O. Internal consistency of the Coopersmith Self-Esteem Inventory. Educational and Psychological Measurement, 1973, 33, 875-876.

Vance, J. J., \& Richmond, O. Cooperative and competitive behavior as a function of selfesteem. Psychology in the Schools, 1975, 12, 225-229.

Whittaker, S. L. Sex differences in self-esteem as a function of assigned masculine and feminine characteristics. (Doctoral dissertation, Michigan State University, 1973). Dissertation Abstracts International, 1973, 34, 1361A. (University Microfilms No. 73-20, 423). 